\title{
Effect of Group B Streptococcal Type-Specific Antigen on Polymorphonuclear Leukocyte Function and Polymorphonuclear Leukocyte- Endothelial Cell Interaction
}

\author{
TERI L. MCFALL, GUY A. ZIMMERMAN, NANCY H. AUGUSTINE, AND HARRY R. HILL \\ Departments of Pediatrics, Medicine and Pathology, University of Utah School of Medicine, Salt Lake City, Utah
}

\begin{abstract}
Neonatal group B streptococcal pneumonia is a severe disease, often resulting in death. Autopsy findings resemble those of hyaline membrane disease. Numerous organisms may be seen in the alveoli, but few polymorphonuclear leukocytes (PMNs) are found in the areas of bacterial invasion. Aggregated PMNs are often found, however, in the pulmonary capillaries. This study was designed to explore the effect of the group B streptococcal (GBS) type III antigen on PMN chemotaxis and PMNendothelial cell interactions. Human PMNs were isolated and pretreated with 0.25 to $4 \mu \mathrm{g} / \mathrm{ml}$ of GBS type III antigen prior to determining their chemotactic response to the chemoattractants formyl-methionyl-leucyl-phenylalanine, zymosan-activated serum, platelet-activating factor, and leukotriene $B_{4}$. The GBS antigen caused a concentrationdependent inhibition of formyl-methionyl-leucyl-phenylalanine, zymosan-activated serum, and platelet-activating factor-mediated chemotaxis $(\%$ inhibition of $38.1 \pm \mathbf{4 . 0}$, $55.5 \pm 3.3,46.7 \pm 9.7 \%$, respectively; $p<0.01$ ). Leukotriene $\mathbf{B}_{4}$-mediated chemotaxis was not significantly depressed $(21.2 \% \pm 7.7$ inhibition; NSD). Group B streptococcal antigen also inhibited formyl-methionyl-leucylphenylalanine-induced PMN adherence to endothelial cells in a concentration-dependent fashion when incubations were performed in the absence of serum. In contrast, incubation of GBS type III antigen with serum deficient in antibody to GBS resulted in a marked enhancement of PMN attachment to human endothelial cells. No significant enhancement of adherence was seen with the antigen in the presence of serum containing GBS type III antibody. These data suggest that the GBS type III antigen by itself may inhibit the influx of PMNs into the local site of infection in the alveoli. In contrast, when exposed to blood components within the vascular space, the antigen may promote PMN adhesion to the endothelium, potentially contributing to pulmonary hypertension, edema, and respiratory failure in this most fulminant of bacterial pulmonary infections of the neonate. (Pediatr Res 21: 517-523, 1987)
\end{abstract}

\section{Abbreviations}

GBS, group B streptococci

PMN, polymorphonuclear leukocytes

Received August 11, 1986; accepted December 23, 1986.

Reprint requests Dr. Harry R. Hill, Division of Clinical Immunology and Allergy, Department of Pediatrics, University of Utah School of Medicine, Salt Lake City, UT 84132.

Supported, in part, by grants from the U.S. Public Health Service (AI13150 and AI19094), the Nora Eccles Treadwell Foundation, the American Lung Association, and an established investigator award from the American Heart Association (G.A.Z.). (T.L.M. received the Lowell A. Glasgow Award for outstanding student research in the Western Society for Pediatric Research for this work in 1986.
fMLP, formyl-methionyl-leucyl-phenylalanine

PAF, platelet-activating factor

ZAS, zymosan-activated serum

HBSS, Hanks' balanced salt solution

TCA, trichloroacetic acid

EC, endothelial cell

$\mathrm{AB}(+)$ serum, serum containing antibody to GBS

$\mathrm{Ab}(-)$ serum, serum deficient in GBS antibody

HBSS/A, HBSS with $0.5 \%$ human serum albumin

C5 $\mathbf{a}_{\text {desarg }}$, desarginated form of C5a

PGI $_{2}$, prostacyclin; prostaglandin $\mathrm{I}_{2}$

$\mathrm{LTB}_{4}$, leukotriene $\mathrm{B}_{4}$

PBS, phosphate-buffered saline

Human disease caused by GBS was first described in 1938 (1). Since that initial report, GBS have been implicated as the cause of several forms of neonatal infection including septicemia, meningitis, and pneumonia (2-6). Pneumonia due to GBS is an extremely severe infection in the human neonate. The chest radiograph is often indistinguishable from that of hyaline membrane disease $(6,7)$. At autopsy, numerous organisms may be seen within the alveoli, but few phagoyctic cells are present in the areas of bacterial invasion (6). In contrast, variable numbers of PMNs are found diffusely throughout the pulmonary capillaries in infants who die from group B streptococcal pneumonia or in experimental animals infused with streptococcal products (68).

One of the major virulence factors of GBS is the type III specific antigen $(9-11)$. This antigen, which is composed of repeating polymers of glucose, galactose, glucosamine, and sialic acid (11), is produced during growth of the type III organisms and released in large quantities into the area surrounding bacterial growth $(9,10)$. Hemming et al. (12) have shown that infusion of a TCA extract containing the type III antigen of GBS-caused leukopenia, increased lung lymph flow, and pulmonary hypertension in sheep. Although the mechanism by which GBS exerts these effects is not clear, it is possible that the antigen alters neutrophil functions resulting in PMN-mediated vascular injury and an altered inflammatory response. In order to investigate this possibility, we examined the effect of the GBS type III antigen on neutrophil chemotaxis in response to the chemoattractants fMLP, C5a fragments in ZAS, PAF, and $\mathrm{LTB}_{4}$. In addition, we examined the effect of the GBS type III antigen on neutrophilendothelial cell interactions.

\section{MATERIALS AND METHODS}

Bacterial cultures and antigen preparation. The type III GBS strain was isolated from the CSF of an infected human infant. 
The antigen was prepared using methods described by Hemming et al. (12) and Lancefield and Freiner (13). GBS type III was grown for $16-18 \mathrm{~h}$ at $37^{\circ} \mathrm{C}$ in 6-18 liters of enriched ToddHewitt broth. The cultures were centrifuged at $5000 \mathrm{rpm}$ at $4^{\circ} \mathrm{C}$ for $30 \mathrm{~min}$. The resulting pellet was washed and suspended in PBS and recentrifuged at $5000 \mathrm{rpm}$ for $1 \mathrm{~h}$ at $4^{\circ} \mathrm{C}$. The pellet was then suspended in cold $2.5 \%$ TCA and the $\mathrm{pH}$ adjusted to 2.0. This suspension was stirred overnight at $4^{\circ} \mathrm{C}$, followed by centrifugation at $5000 \mathrm{rpm}$ for $45 \mathrm{~min}$ at $4^{\circ} \mathrm{C}$. The supernatant containing the antigen was then treated with cold $95 \%$ ethanol so that ethanol comprised $60 \%$ of the total volume and incubated at $4^{\circ} \mathrm{C}$ overnight. This ethanol fraction was centrifuged at 5000 $\mathrm{rpm}$ at $4^{\circ} \mathrm{C}$ for $45 \mathrm{~min}$. The precipitate was separated from the supernatant and centrifuged at $3300 \mathrm{rpm}$ for $30 \mathrm{~min}$. The precipitate was resuspended in $0.5-1 \mathrm{ml}$ of PBS and the $\mathrm{pH}$ adjusted to approximately 7.0. Purity of the type III antigen was determined using capillary precipitation methods and by counterimmunoelectrophoresis. The extract reacted only with type III rabbit antiserum. No group antigen was present. The antigen preparation was free of endotoxin when assayed by the limulus lysate assay and by examining it's ability to directly stimulate PMN adhesion to nylon fiber columns. The antigen was stored at $4^{\circ} \mathrm{C}$. Serial dilutions of the antigen were made in the control buffer appropriate for the experiment.

We also employed a highly purified type III antigen (a gift of Dr. Bascom Anthony, Harbor-UCLA Medical School) which had been isolated by column separation of concentrated culture supernatants (14). The concentration of the GBS antigen prepared by TCA and ethanol fractionation was determined by comparison with the known standard supplied to us by Dr. Anthony. In limited experiments, the highly purified type III antigen standard was also utilized in the functional assays. The results with both antigen preparations were essentially identical.

Complement assays. Complement consumption analysis was performed by incubating fresh, frozen GBS antibody-positive and antibody-negative serum with $20 \mu \mathrm{g} / \mathrm{ml}$ of the type III antigen for $60 \mathrm{~min}$ at $37^{\circ} \mathrm{C}$. Total hemolytic complement levels in sera were determined before and after exposure to the antigen by a radial hemolytic technique $\left(\mathrm{CH}_{100}\right.$; Behring Diagnostics, $\mathrm{La}$ Jolla, CA) and by hemolytic titration with antibody-coated sheep red blood cells $\left(\mathrm{CH}_{50}\right)(15)$. The concentration of $\mathrm{C} 5 \mathrm{a}_{\text {desarg }}$ in the sera following antigen incubation was determined with a commercially available radioimmunoassay kit (Upjohn, Kalamazoo, MI).

Human neutrophil isolation. Neutrophil suspensions were prepared by collecting peripheral venous blood from healthy human adult volunteers in heparin, $7.5 \mathrm{U} / \mathrm{ml}$. The blood was allowed to settle in $1 \%$ dextran (Pharmacia, Piscataway, $\mathrm{NJ}$ ) and the neutrophils were separated on Ficoll-Hypaque (Pharmacia) gradients. Contaminating red cells were removed by hypotonic lysis with $0.2 \%$ saline. The remaining neutrophils $(98 \%)$ were resuspended to a concentration of $2 \times 10^{7} \mathrm{PMNs} / \mathrm{ml}$ in HEPES buffer with $1 \%$ bovine serum albumin for the chemotaxis assays. The cells were resuspended in HBSSIA (M.A. Bioproducts, Walkersville, MD) for endothelial cell-granulocyte adherence assays. Some of the experiments required pretreatment of the neutrophils with the GBS type III antigen. Appropriate volumes of the antigen were added to known volumes of the neutrophil suspensions and incubated at $37^{\circ} \mathrm{C}$ for $30 \mathrm{~min}$ prior to use in functional assays. In endothelial cell adherence assays, the neutrophils were radiolabeled with Indium 111 as described (16).

Neutrophil chemotaxis. Neutrophil chemotaxis was assayed using a multiwell micropore chemotaxis chamber (Neuroprobe, Cabin John, MD) with a $5 \mu$ pore size filter (Millipore Corp., Bedford, MA) according to previously described methods (1719). The bottom chambers were filled with $30 \mu \mathrm{l}$ of chemoattractant or control buffer. The filters were inserted and then the upper chambers were filled with $50 \mu \mathrm{l}$ of the appropriate neutrophil or neutrophil-GBS type III antigen suspensions.

Chambers were incubated at $37^{\circ} \mathrm{C}$ in a humidified chamber with $5 \% \mathrm{CO}_{2}$ for $2 \mathrm{~h}$. Filters were removed and stained with hematoxylin. Neutrophils that migrated completely through the filter were counted using a $10 \times$ ocular, a $45 \times$ objective, and a 5 $\times 5 \mathrm{~mm}$ photographic reticule. Chemotaxis was quantitated by determining the mean number of cells that migrated completely through the filter in 10 random fields. Assays were performed in triplicate on three or more occasions in most instances. Neutrophil viability was determined for neutrophils treated with control buffer and GBS type III antigen at the end of the incubation time using a trypan blue stain.

Chemoattractant. ZAS was prepared by incubating $10 \mathrm{ml}$ of fresh human serum with $100 \mathrm{mg}$ of washed zymosan (Schwarz/ Mann, Biotech Division of ICN Biochemicals, Cleveland, $\mathrm{OH}$ ) for $60 \mathrm{~min}$ at $37^{\circ} \mathrm{C}$ in a rotating rack. Following centrifugation, the clarified activated serum was stored in aliquots at $-70^{\circ} \mathrm{C}$. For use, the ZAS was diluted in HEPES buffer or HBSS to a concentration of $10 \%$. fMLP (Sigma Chemical Co., St. Louis, MO) was prepared as a $10^{-5} \mathrm{M}$ stock solution in HEPES buffer, stored at $-70^{\circ} \mathrm{C}$, and diluted to the appropriate concentration in HEPES buffer immediately before use. PAF was purchased from Avanti Polar Lipids, Inc. (Birmingham, AL). LTB 4 was a gift from Dr. Joshua Rokach (Merck-Frosst Canada, Inc., Quebec, Canada).

Endothelial cell isolation and culture. EC were isolated from human umbilical veins as previously described $(16,20)$. Briefly, the cells were isolated by collagenase perfusion of umbilical veins and suspended in medium 199 supplemented with $20 \%$ pooled human serum, L-glutamine, and antibiotics (M.A. Bioproducts, Walkersville, MD) (20). The cells were cultured in $35-\mathrm{mm}$ polystyrene Petri dishes (Corning Glass Works, Corning, NY) in a $5 \% \mathrm{CO}_{2}, 95 \%$ air atmosphere until confluence was reached (5-7 days). The media were changed every $72 \mathrm{~h}$. Cells grown in this fashion were documented to be endothelial cells by several criteria including contact-inhibited monolayer morphology, the presence of von Willebrand factor, angiotensin-converting enzyme activity, and the production of $\mathrm{PGI}_{2}$ in response to appropriate agonist stimulation $(16,20)$. These criteria taken together are unique for endothelial cells and are shared by no other cell type. Only tightly confluent, primary cultures were used for these experiments.

Adherence of labeled neutrophils to endothelial cell monolayers. The adherence of ${ }^{111}$ In-labeled PMNs to EC monolayers was measured as described (16). The culture medium was aspirated, and the monolayers were washed with $\operatorname{HBSS}\left(37^{\circ} \mathrm{C}\right)$. Aliquots $\left(0.9 \mathrm{ml}\right.$ containing $5 \times 10^{6}$ cells $)$ of labeled PMN suspensions were layered over the endothelial monolayers. Control buffer, buffer containing an agonist (fMLP, etc, used as a positive control), or type III GBS antigen was then added $(0.1 \mathrm{ml})$ and the suspensions were incubated in an atmosphere of $5 \% \mathrm{CO}_{2}$, $95 \%$ air at $37^{\circ} \mathrm{C}$ for varying times as indicated. After incubation, the neutrophils remaining in suspension were aspirated, the monolayers were washed, and the percentage of adherent PMNs was quantitated as described (16). The EC monolayers were also examined by phase contrast microscopy immediately before and immediately after incubation with PMNs to insure that the monolayers were intact and that the PMNs were adherent to the top surface of the confluent EC monolayers. In previous studies (16) we have also documented the adhesion by electron microscopy.

In some experiments, labeled neutrophils, or EC monolayers, were pretreated with various concentrations of the type III GBS antigen for 5 or $30 \mathrm{~min}$ at $37^{\circ} \mathrm{C}$ prior to the adherence assay. In additional experiments, whole human serum with or without type III-specific ELISA or opsonophagocytic antibody (determined as previously described) (21) was added (10\% v/v) to labeled PMNs in the presence or absence of the type III antigen. Neutrophil adherence to the monolayers was then determined after varying time intervals.

Adherence of indium-labeled neutrophils to nylon fiber columns. Columns containing nylon fibers were constructed as 
previously described (16) and warmed to $37^{\circ} \mathrm{C}$. Aliquots of ${ }^{111}$ In-labeled neutrophils ( $0.9 \mathrm{ml}$ containing $\left.5 \times 10^{6} \mathrm{PMNs}\right)$ were mixed with control buffer or agonist solutions $(0.1 \mathrm{ml})$ for $30 \mathrm{sec}$ to $5 \mathrm{~min}$ at $37^{\circ} \mathrm{C}$ on a mixing platform. Then $1.0-\mathrm{ml}$ volumes were added to the columns and allowed to drain by gravity at $37^{\circ} \mathrm{C}$ for $15 \mathrm{~min}$. The radioactivity from the columns and the effluent were counted separately. The percentage of neutrophils adherent to the column was determined by dividing the radioactivity associated with the column by the sum of the radioactivities from the column and the effluent (15).

Neutrophil aggregation. The aggregation of neutrophil preparations suspended in HBSS/A in response to GBS type III antigen or agonists (fMLP, etc.) was measured as described using an aggregometer (22).

Data comparisons. All results were recorded as the mean \pm SD. Statistical differences were determined using a paired Student's $t$ test.

\section{RESULTS}

Effect of GBS type III antigen on neutrophil chemotaxis. We examined the GBS antigen that was employed with the more highly purified antigen (supplied by Dr. Anthony) by double immunodiffusion and electroimmunodiffusion against hyperimmune antiserum to the type III polysaccharide. As can be seen in Figure 1, lines of identity develop between the two antigens exposed to this antiserum. Moreover, immunoelectrophoresis of similar concentrations of the antigens against the hyperimmune rabbit antiserum yielded similar precipitin bands approximately the same distance from the antigen wells (Fig. 2). This indicates probable similarity of the charge and approximate molecular weight of the antigens.

As shown in Figures 3 and 4, the chemotactic activity of neutrophils was inhibited by treatment of the cells with the type III GBS antigen. The magnitude of inhibition varied with the chemotactic agent used as the stimulus. In response to $10^{-8} \mathrm{M}$ fMLP the mean number of neutrophils that completely migrated

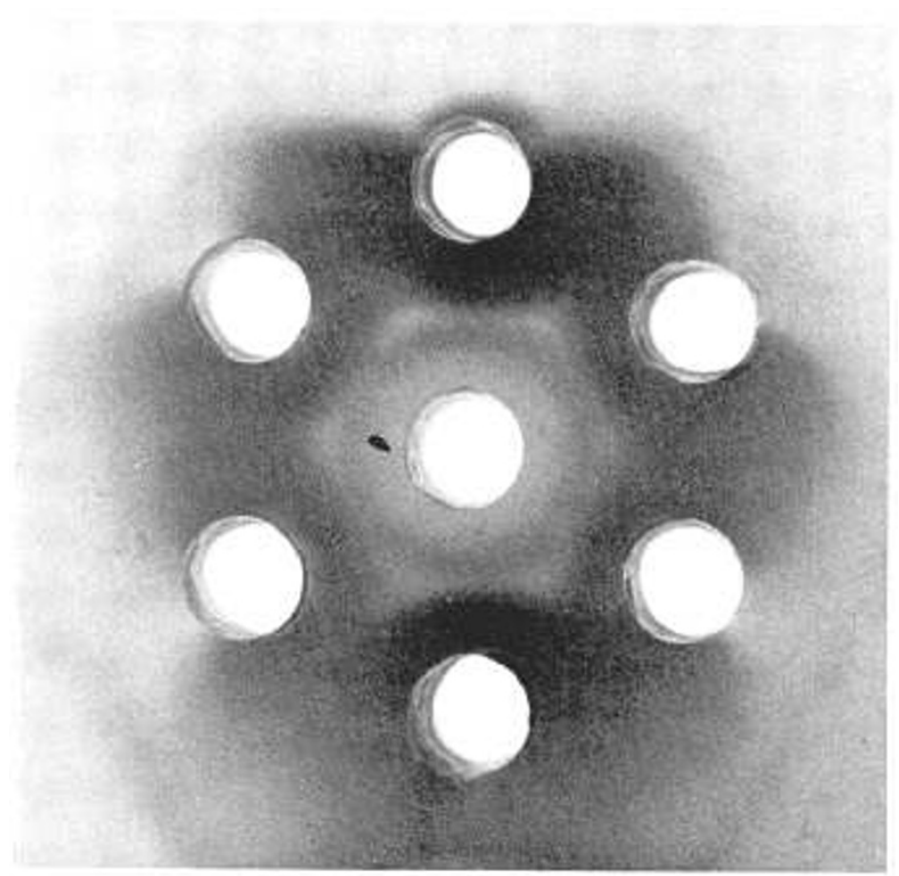

Fig. 1. Analysis of immunologic identity of the TCA antigen and the column purified GBS type III antigen. Rabbit hyperimmune type III antiserum was placed in the center well. The purified type III antigen was placed in the top and bottom wells, while the TCA extracted type III antigen was placed in the left and right wells. A distinct line of identity is apparent between the two antigen preparations.

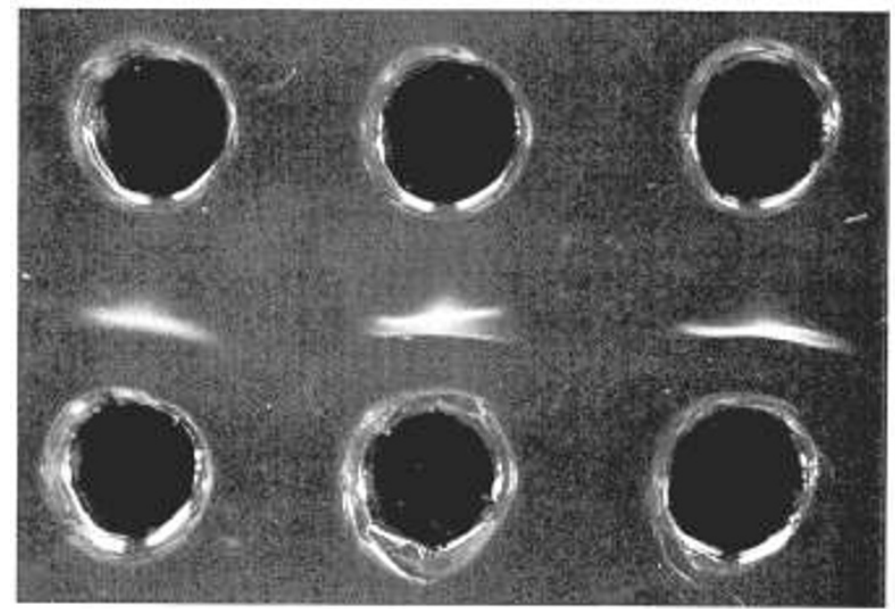

Fig. 2. Electroimmunodiffusion analysis of the purified type III antigen and the TCA extracted antigen. Equal quantities $(10 \mu \mathrm{g} / \mathrm{ml})$ of the TCA antigen were placed in the outside wells along with the purified type III antigen in the center well. The antigens were placed nearest to the cathode (top). A hyperimmune, rabbit type III specific serum was placed in the wells nearest the anode (bottom) and electrophoresis was carried out in barbital buffer ( $\mathrm{pH} 8.8$ ) at 6 milliamps per slide for 60 $\min$.

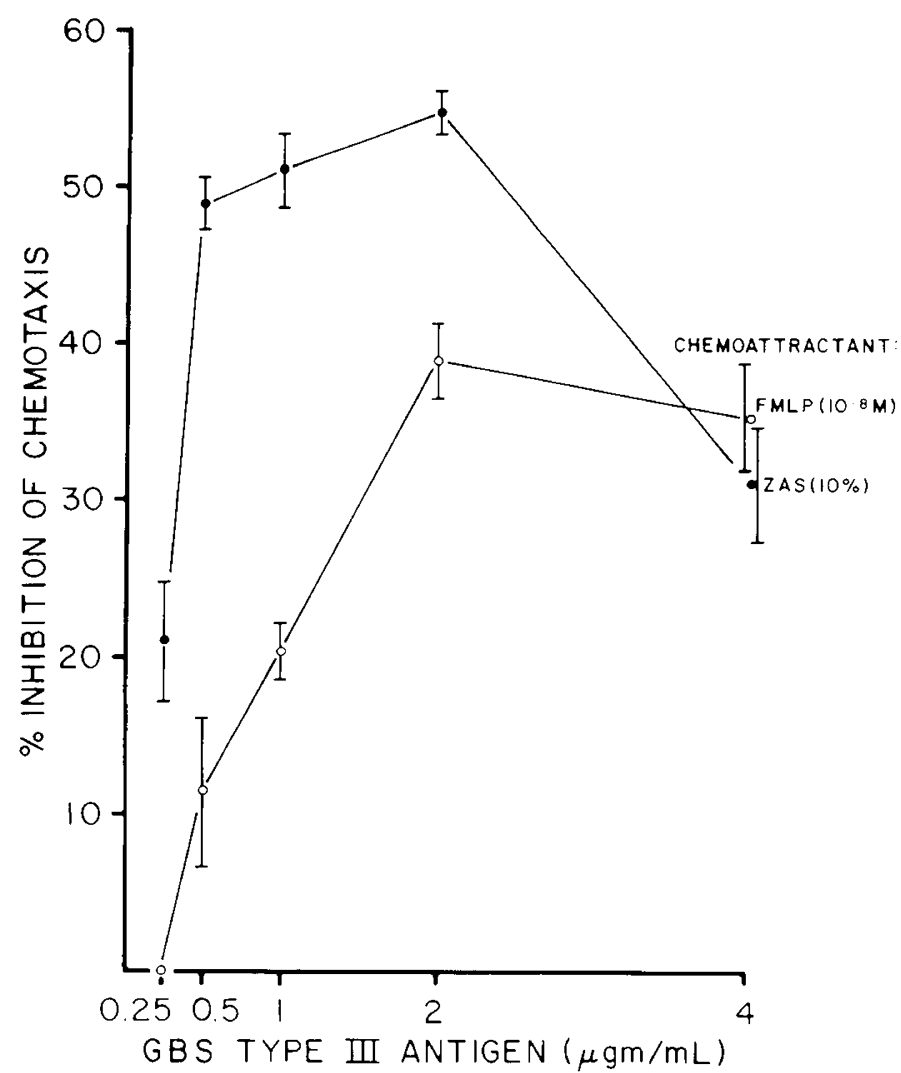

Fig. 3. Effect of the type III GBS antigen on PMN chemotactic responses to $10 \% \mathrm{ZAS}$ and $\mathrm{fMLP}\left(10^{-8} \mathrm{M}\right)$.

through the filter was $78.4 \pm 12.1$ (SD) when the cells were pretreated with control buffer. No significant effect on chemotaxis was observed when the cells were pretreated with $0.25,0.5$, or $1 \mu \mathrm{g} / \mathrm{ml}$ of GBS type III antigen (Fig. 3). Significant inhibition was observed, however, with 2 and $4 \mu \mathrm{g} / \mathrm{ml}$ of the GBS type III antigen $(p<0.01)$.

When $10 \%$ ZAS was used as the chemoattractant, the mean number of cells migrating completely through the filter was 54.8 \pm 5.0 (SD) in the buffer control. Chemotaxis was inhibited 


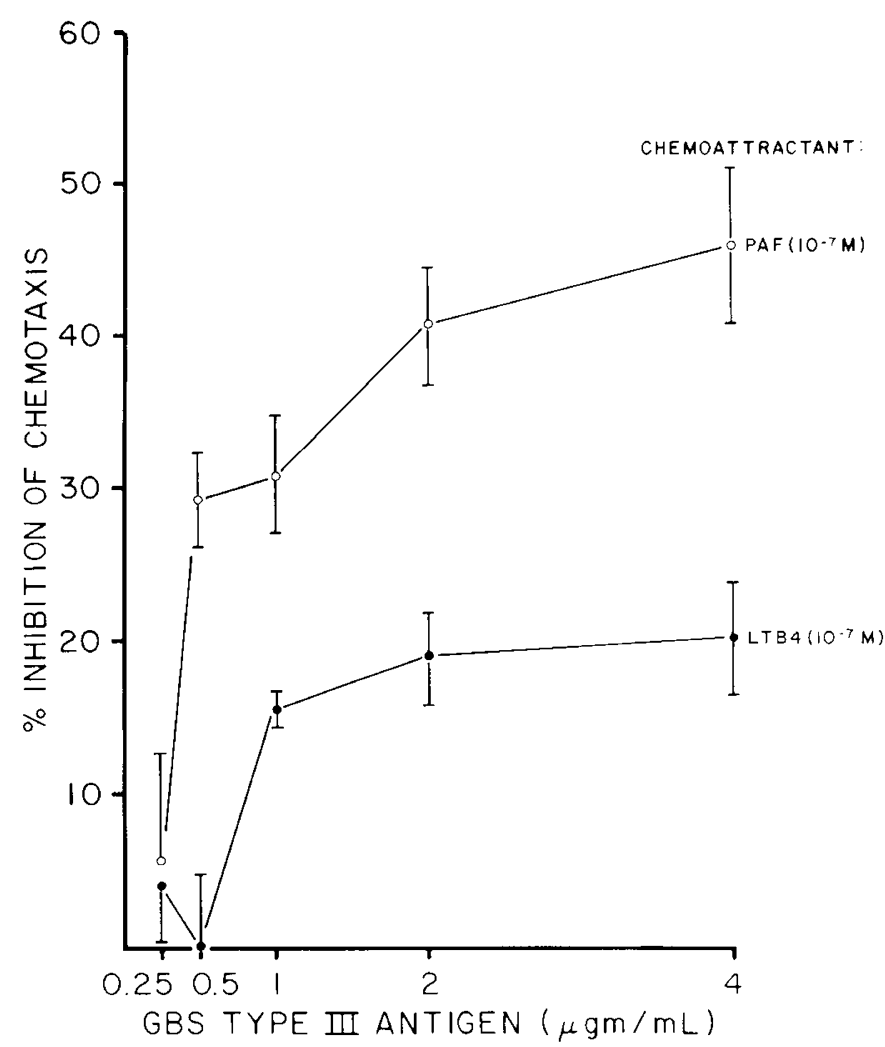

Fig. 4. Effect of the type III GBS antigen on PMN chemotactic responses to PAF $\left(10^{-7} \mathrm{M}\right)$ and $\mathrm{LTB}_{4}\left(10^{-7} \mathrm{M}\right)$.

following pretreatment of the neutrophils with $0.5 \mu \mathrm{g} / \mathrm{ml}(p<$ $0.01), 1 \mu \mathrm{g} / \mathrm{ml}(p<0.01)$, and $2 \mu \mathrm{g} / \mathrm{ml}(p<0.01)$ of the type III antigen (Fig. 3).

Neutrophil chemotaxis in response to $10^{-7} \mathrm{M}$ PAF was also significantly inhibited by pretreatment with GBS type III antigen at 2 and $4 \mu \mathrm{g} / \mathrm{ml}$ (Fig. 4). The mean number of cells migrating completely through the filter after pretreatment with control buffer was $94.3 \pm 5.1$ (SD). This was compared with means of $55 \pm 7.04$ at $2 \mu \mathrm{g} / \mathrm{ml}$ antigen $(p<0.01)$ and $50.2 \pm 4.5$ at $4 \mu \mathrm{g} /$ $\mathrm{ml}$ antigen $(p<0.01)$. These data demonstrate that the GBS type III antigen inhibits the chemotactic response to a potent lipid mediator of inflammation, PAF, in addition to the oligopeptide chemoattractants FMLP and $C 5 \mathrm{a}_{\text {desArg. }}$.

Chemotaxis in response to $\mathrm{LTB}_{4}$, another potent lipid inflammatory mediator, was also reduced after pretreatment of the neutrophils with GBS antigens but the degree of reduction was not significantly different from control (Fig. 4). The mean number of cells migrating through the filter after incubation with buffer alone was $115 \pm 7.6$ (SD). At the maximum concentration of $4 \mu \mathrm{g} / \mathrm{ml}$ of GBS type III antigen, the mean number of cells migrating through the filter was not statistically different $(90.5 \pm$ $8.8 ; p>0.05)$. This corresponded to only $21.1 \pm 7.7 \%$ inhibition. Trypan blue staining of GBS type III antigen-treated and buffertreated neutrophils at the end of the incubation time indicated no increase in neutrophil death secondary to treatment with the GBS antigen. Neutrophil viability ranged from $92-99 \%$ for all samples. Thus, the inhibition of PMN chemotaxis by GBS type III antigen was not due to cytotoxic injury of the neutrophils.

Effect of GBS antigen on neutrophil-endothelial cell adherence. Because Hemming et al. (12) observed leukopenia in association with pulmonary vascular injury in sheep infused with GBS products, we sought evidence that the GBS type III antigen promoted neutrophil adhesion to other PMNs (aggregation), to inert surfaces (nylon fiber columns), or to endothelium. In preliminary experiments, whole live GBS, an ultrafiltrate of GBS, and GBS type III antigen alone did not increase neutrophil adherence to nylon fiber columns and did not stimulate neutrophil aggregation when added in various concentrations to isolated neutrophils suspended in HBSS/A. These data indicated that GBS type III antigen alone did not directly stimulate cell-cell adhesion (aggregation) or the adhesion of isolated neutrophils to inert surfaces $(16,22)$.

We then proceeded to examine the effect of GBS type III antigen on what is perhaps a more relevant system, neutrophil adherence to human endothelial cell monolayers. In experiment I of Table 1, we determined the direct effect of the type III antigen on untreated PMN interaction with untreated endothelial cells. As shown, the type III antigen decreased adherence at 5 min while the known positive adherence agonist fMLP markedly enhanced attachment (Table 1 , experiment I).

We next considered the possibility that pretreatment of the endothelial cells with the GBS type III antigen might promote neutrophil adherence, as do thrombin (16), interleukin-1 (23), and other agents including endotoxin (24-26). Pretreatment of endothelial cells with GBS type III antigen, followed by washing the monolayers prior to the addition of neutrophils, did not stimulate neutrophil adherence (Table 1, experiment II), as did the known positive agonist thrombin or FMLP. This result indicates that the GBS product does not directly enhance the adhesiveness of EC. Furthermore, it suggests that the lack of a proadhesive effect of the GBS type III antigen in experiment I (under conditions in which GBS type III antigen, PMNs, and endothelial cells were incubated together) was not due to the concomittant release of an inhibitor of PMN adhesion, such as $\mathrm{PGI}_{2}$, by the endothelial cells (20).

In a third experiment, preincubation of PMNs with the GBS type III $\mathrm{Ag}$ for $30 \mathrm{~min}$ at $37^{\circ} \mathrm{C}$ also resulted in depression of adherence while the positive agonist FMLP increased adherence (Table 1, experiment III).

In another experiment, pretreatment of neutrophils with GBS type III antigen for $30 \mathrm{~min}$ at $37^{\circ} \mathrm{C}$ resulted in a concentrationdependent inhibition of fMLP-stimulated adhesion (Table 1, experiment IV). This result was similar to the effect of pretreatment of the neutrophils with GBS type III antigen on fMLPstimulated chemotaxis, which also resulted in inhibition (Fig. 1). However, the concentration of antigen required for significant inhibition of adherence $(20 \mu \mathrm{g} / \mathrm{ml})$ was higher than that required to inhibit chemotaxis $(2 \mu \mathrm{g} / \mathrm{ml})$. The results of experiments I-IV in Table 1 indicated that GBS type III antigen did not directly stimulate PMN adherence to EC, and that it diminished chemotactic factor-stimulated adherence when the incubations were performed in aqueous buffer.

We next considered it possible that the effect of GBS type III antigen on PMN adherence to EC might be different in the presence of serum, since serum contains a variety of plasmaderived inflammatory mediators $(16,27-29)$. We examined, therefore, the effect of serum on neutrophil adherence in the presence or absence of GBS type III antigen. As shown in experiment $\mathrm{V}$ in Table 1 addition of whole human serum that contained antibody to the type III GBS antigen by ELISA employing a TCA extracted antigen and opsonophagocytic assay $[\mathrm{Ab}(+)$ serum; ELISA titer 1:1024] or serum that was deficient in antibody to type III GBS [Ab(-) serum; ELISA titer 1:16] caused greater adherence than did control buffer or GBS type III antigen alone (172 and 135-146\% of control). Enhancement of PMN adherence to human endothelium by normal serum alone has been previously reported by Harlan et al. (30) and is probably due to the presence in normal serum of thrombin and other factors (23-26). Of note is the fact that these specimens contained essentially equivalent levels of fibronectin $[\mathrm{AB}(+)$ serum; 240 $\mu \mathrm{g} / \mathrm{ml}$ versus $\mathrm{AB}(-)$ serum $230 ; \mu \mathrm{g} / \mathrm{ml}]$ as determined spectrophotometrically. Addition of GBS type III antigen to $\mathrm{Ab}(-)$ serum further enhanced neutrophil adherence $(315 \%)$ to more than 2-fold that of the level seen with $\mathrm{AB}(-)$ serum alone $(146 \%)$. Moreover, the values remained elevated after $30 \mathrm{~min}(300 \%)$ of incubation. Similar results were seen when whole live GBS were 
Table 1. Effect of GBS type III antigen (Ag) on PMN adherence to human endothelial cells*

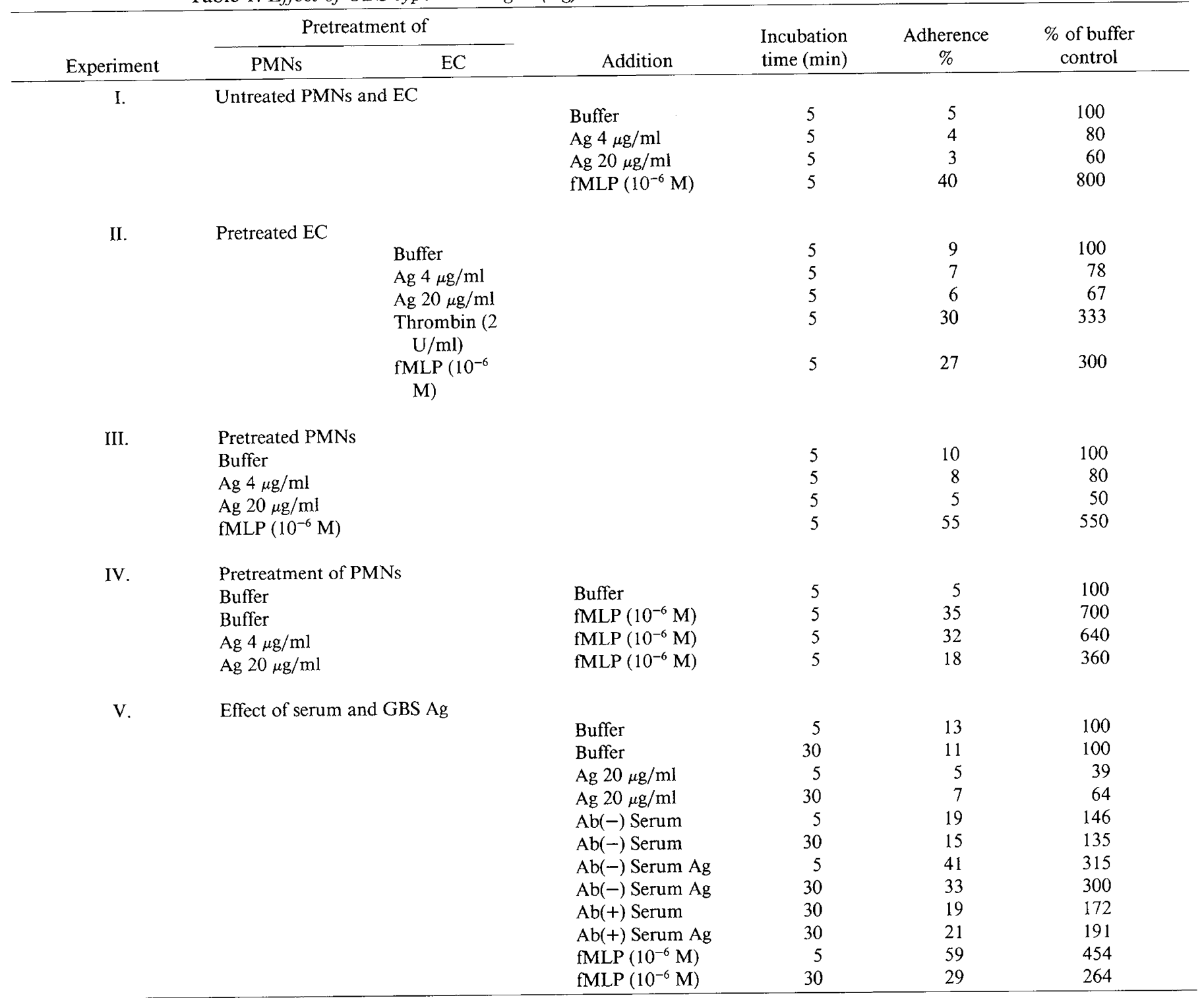

* Nine-tenths $\mathrm{ml}$ of a suspension containing $5.5 \times 10^{6} \mathrm{PMNs}$ per ml was added to each monolayer and the percentage bound determined.

Table 2. Effect of type III GBS antigen on complement consumption and generation of $C 5 a_{\text {desarg }}$ as determined by

\begin{tabular}{|c|c|c|c|}
\hline Incubation mixture & $\begin{array}{c}\text { Total } \\
\text { hemolytic } \\
\mathrm{CH}_{100} \\
\text { Units }\end{array}$ & $\begin{array}{l}\text { Complement } \\
\mathrm{CH}_{50} \text { Units }\end{array}$ & $\begin{array}{c}\text { C5a by } \\
\text { RIA } \\
(\mathrm{ng} / \mathrm{ml})\end{array}$ \\
\hline $\begin{array}{l}\text { Fresh antibody }(+) \\
\text { serum }\end{array}$ & 150 & 48 & $<10$ \\
\hline $\begin{array}{l}\mathrm{Ab}(+) \text { serum + GBS Ag } \\
20 \mu \mathrm{g} / \mathrm{ml}\end{array}$ & 56 & 4 & 56 \\
\hline $\mathrm{Ab}(-)$ serum & 150 & 96 & $<10$ \\
\hline $\begin{array}{l}\mathrm{Ab}(-) \text { serum + GBS Ag } \\
20 \mu \mathrm{g} / \mathrm{ml}\end{array}$ & 150 & 96 & $<10$ \\
\hline
\end{tabular}

added to $\mathrm{Ab}(-)$ serum (data not shown). The enhanced PMN adherence in the presence of GBS type III antigen and $\mathrm{Ab}(-)$ serum approached the magnitude of adherence stimulated by fMLP at $5 \mathrm{~min}(454 \%)$ and exceeded it at $30 \mathrm{~min}(264 \%)$. In contrast, GBS type III antigen did not significantly stimulate
PMN adherence in the presence of $\mathrm{Ab}(+)$ serum (191\%) above that with $\mathrm{AB}(+)$ serum $(172 \%)$ alone. The stimulating effect of GBS type III antigen in the presence of $\mathrm{Ab}(-)$ serum was not due to the generation of C5a fragments, since the same preparation of GBS antigen did not cause complement activation in aliquots of the $A b(-)$ serum and did not generate $C 5 \mathrm{a}_{\text {desarg }}$ as determined by radioimmunoassay (Table 2). This is consistent with the recognized requirement for antibody in order for the sialic acid containing type III antigen to activate complement. The antibody-positive serum did activate complement in the presence of the type III antigen resulting in C5a generation. This did not, however, significantly enhance PMN-EC adherence suggesting that complement-derived components are not responsible for the enhancement we observed.

In an experiment designed to determine if the enhanced adhesion of PMN to EC in the presence of GBS type III antigen and $\mathrm{Ab}(-)$ serum was due to increased adhesiveness of the neutrophils or the EC, we incubated GBS antigen and $10 \%(\mathrm{Ab}(-)$ serum with neutrophils and assessed their adherence to nylon fiber columns. Adherence in the presence of GBS antigen and $\mathrm{Ab}(-)$ serum was $160 \%$ of that in response to GBS type III antigen alone, suggesting that at least part of the effect resulted 
from an increase in neutrophil adhesiveness, per se. The type III antigen had no effect on adhesiveness in the presence of antibodypositive serum.

\section{DISCUSSION}

The experiments described herein suggest that GBS type III antigen alters human neutrophil functional responses, and that the alteration may be influenced by other humoral mediators such as those found in serum. Our observations may be relevant to events that occur in vivo during episodes of group B streptococcal pneumonia and bacteremia which result in impaired PMN migration into the alveoli in the face of intravascular sequestration of these cells $(6,8)$.

We found that neutrophil chemotaxis in response to fMLP and C5a fragments in ZAS was inhibited in a concentrationdependent fashion by the GBS type III antigen. The mechanism of this inhibition is not clear. Neutrophil chemotaxis occurs in response to fMLP and C5a only after these peptides bind to specific cell surface receptors. Of interest is a recent report by Perez et al. (31), indicating that the plant lectin, wheat germ agglutinin, irreversibly inhibits human PMN chemotaxis to fMLP. This probably results from binding of the agglutinin to $\mathrm{N}$-acetylglucosamine residues present in surface glycoproteins important in stimulus-response coupling in the PMN (31). This inhibition occurs even though there is no direct effect of the lectin to decrease labeled fMLP binding. Gray et al. (32) have shown that the type III antigen of GBS also binds directly to the wheat germ agglutinin through sialic acid. The structural relationships here suggest that there may be a competitive type of inhibition between the type III antigen and receptors important in stimulus-response coupling that results in the impaired response to fMLP. [In results similar to those reported (31) with the wheat germ agglutinin, however, we could show no direct effect of the GBS type III antigen on labeled fMLP binding to PMNs; data not shown.] Furthermore, the type III antigen inhibited chemotaxis in response to C5a and PAF, agents that have receptors separate from those for fMLP. These results suggest a pleiotropic inhibition of the PMN chemotactic response by the GBS type III antigen. We found, however, that the mean chemotactic response to $\mathrm{LTB}_{4}$, a potent endogenous lipid mediator, was not significantly depressed by the type III antigen. The lack of a significant effect of the type III antigen on this mediator may have been due to the fact that the $\mathrm{LTB}_{4}$ was the most potent chemoattractant that we used, or to the possibility that it activates cells in a unique manner (33).

One potential mechanism for the pleiotropic inhibition of PMN chemotaxis by the type III GBS antigen is the stimulation of markedly enhanced, irreversible adherence of the PMNs to surfaces resulting in their inability to migrate. We explored this possibility by examining the effect of the GBS antigen on PMN adhesiveness under a variety of conditions. We found that the type III GBS antigen did not directly stimulate PMN aggregation, adherence to nonbiologic surfaces (nylon fiber), or to human endothelium when incubations were carried out in buffer. Thus, the type III antigen does not directly enhance the adhesiveness of PMNs, as do fMLP, C $5 \mathrm{a}_{\text {desArg, }}$ and certain other agonists. These results appear to exclude PMN hyperadhesiveness as the mechanism for impaired in vitro chemotaxis caused by the GBS antigen. Our experiments with endothelial monolayers (Table 1) also exclude a direct effect of the GBS type III antigen on endothelial cell adhesiveness such as that produced by alpha thrombin and leukotriene $\mathrm{C}_{4}(16,24)$.

Although GBS type III antigen did not stimulate neutrophil adhesion to endothelial cell monolayers alone, there was a rapid, potent, and prolonged stimulation of adherence in the presence of whole human serum lacking type-specific GBS antibody (Table 1). A similar effect was observed when live type III group B streptococcal organisms were utilized instead of the type-specific antigen. Thus, either whole organisms or the type-specific anti- gen, in the presence of one or more serum components, alter neutrophil-endothelial cell interaction resulting in enhanced adherence. Whether this effect is due to a potentiation of a direct effect of an agent such as kallikrein on the neutrophil (27), an enhancement of the effect of a mediator such as thrombin on the endothelial cells (16), or another mechanism remains to be determined. The experiment showing that the GBS type III antigen in the presence of serum enhanced PMN adhesiveness to nylon wool columns suggests that the first thesis may be functional. The enhanced interaction between PMNs and endothelial cells as well as the increased adherence of PMNs to nylon wool in the presence of the type III antigen and $\mathrm{Ab}(-)$ serum did not appear to be due to activation of the complement cascade and the generation of $\mathrm{C} 5 \mathrm{a}$ and $\mathrm{C} 5 \mathrm{a}_{\text {desArg, }}$ since the type III antigen did not promote complement consumption or the release of $\mathrm{C} \mathrm{a}_{\text {desarg }}$ in serum which lacked antibody. Antibody appears to be an absolute requirement for complement activation with type III GBS or with the mildly extracted (2.5\% TCA in the cold) sialic acid containing type III antigen (34).

Of interest was the fact that the type III antigen did not promote neutrophil adherence in serum that contained typespecific antibody when compared to the antibody-positive serum alone. These results are very similar to those of Wood and Gray (35) who found that type-specific antibody prevented platelet aggregation by plasma exposed to the type III antigen. This suggests that antibody may prevent the interaction of the antigen with the serum components responsible for promoting adherence, and is consistent with our earlier observations showing that antibody protects newborn rats from respiratory infections due to group B streptococci (21) and prevents the diffuse accumulation of PMNs throughout both lung fields observed in untreated, infected animals (36). This occurs even though there is complement activation and the generation of $\mathrm{C} 5 \mathrm{a}$ by the interaction of antibody with the antigen. These data suggest that the mediator of the enhanced adherence is derived from factors other than those of the complement system.

Our experiments suggest that in the presence of serum components, the GBS type III antigen promotes neutrophil adherence to the endothelial surface. This event may result in pulmonary vascular injury (37) and may partially explain the leukopenia, pulmonary hypertension, and edema observed in human or experimental GBS pulmonary disease $(6,8,12)$. Alternatively, release of this antigen in large amounts within the infected alveoli where serum components are not present in large quantities may actually decrease the influx of inflammatory cells through an effect to directly depress PMN chemotaxis. Together, these effects on neutrophil function may contribute to the altered inflammatory response and pathophysiology of group B streptococcal infection within the lungs of neonates.

Acknowledgments. The authors thank Dr. Bascom Anthony and Dr. Joshua Rokach for the gift of biologic materials, Betsy Morris and Donelle Benson for excellent technical assistance, Deborah Camomile for careful preparation of this manuscript, and Don Morse for excellent art work and photography.

\section{REFERENCES}

1. Fry RM 1938 Fatal infections by hemolytic streptococcus group B. Lancet 1:199-201

2. Anthony BF, Okada DM 1977 The emergence of group B streptococci in infections of the newborn infant. Ann Rev Med 28:355-369

3. Howard JB, McCracken GH Jr 1974 The spectrum of group B streptococcal infections in infancy. Am J Dis Child 128:815-818

4. Yow M 1974 Group B streptococci: a serious threat to the neonate. JAMA 230:1177-1178

5. Barton LL, Feigin RD, Lens R 1973 Group B beta-hemolytic streptococcal meningitis in infants. J Pediatr 82:719-723

6. Katzenstein A, Davis C, Braude A 1976 Pulmonary changes in neonatal sepsis due to group B beta-hemolytic streptococcus: relation to hyaline membrane disease. J Infect Dis 133:430-435

7. Hemming VG, McCloskey DW, Hill HR 1976 Pneumonia in the neonate associated with group B streptococcal septicemia. Am J Dis Child 130:1231- 
1233

8. Rojas J, Larsson LE, Hellerquist CG, Brigham KL, Gray ME, Stahlman MT 1983 Pulmonary hemodynamic and ultrastructural changes associated with group B streptococcal toxemia in adult sheep and newborn lambs. Pediatr Res 17:1002-1008

9. Young MK, Mattingly SJ 1984 Biosynthetic capacity for type-specific antigen synthesis determines the virulence of serotype III strains of group B streptococci. Infect Immun 44:217-221

10. Doran TI, Straus DC, Mattingly SJ 1980 Extracellular antigens of serotype III group B streptococci. Infect Immun 30:890-893

11. Jennings HJ, Rosell K, Kasper DL 1980 Structural determination and serology of the native polysaccharide antigen of type-III group B Streptococcus. Can J Biochem 58:112-120

12. Hemming VG, O'Brien WF, Fischer GW, Golden SM, Noble SF 1984 Studies of short-term pulmonary and peripheral vascular responses induced in oophorectomized sheep by the infusion of a group B streptococcal extract. Pediatr Res 18:266-269

13. Lancefield RC, Freimer EH 1966 Type specific polysaccharide antigens of group B streptococci. J Hyg 64:191-203

14. Anthony BF, Concepcion NF, McGeary SA, Ward JI, Heiner DC, Shapshak P, Insel RA 1982 Immunospecificity and quantitation of an enzyme-linked immunosorbent assay for group B streptococcal antibody. J Clin Microbiol 16:350-354

15. Shigeoka AO, Jensen CL, Pincus SH, Hill HR 1984 Absolute requirement for complement in monoclonal IgM antibody-mediated protection against experimental infection with type III group B streptococci. J Infect Dis 150:6370

16. Zimmerman GA, McIntyre TA, Prescott SM 1985 Thrombin stimulates the adherence of neutrophils to human endothelial cells in vitro. J Clin Invest $76: 2235-2246$

17. Falk W, Goodwin RH Jr, Leonard EJ 1980 A 48 well micro chemotaxis assembly for rapid and accurate measurement of leukocyte migration. $J$ Immunol Methods 33:239-247

18. Harvath L 1980 Rapid quantitation of neutrophil chemotaxis: Use of a polyvinylanolidone-free polycarbonate membrane in a multiwell assembly. J Immunol Methods 37:39-45

19. Hill HR, Gerrard JM, Hogan NA, Quie PG 1974 Hyperactivity of neutrophil leukotactic responses during active bacterial infection. J Clin Invest 53:9961002

20. Zimmerman GA, Wiseman GA, Hill HR 1985 Human endothelial cells modulate granulocyte adherence and chemotaxis. J Immunol 134:18551874

21. Shigeoka AO, Pincus SH, Rote NS, Hill HR 1984 Protective efficacy of hybridoma type-specific antibody against experimental infection with group B streptococcus. J Infect Dis 149:363-372

22. Zimmerman GA, Klein-Knoeckel D 1986 Human endothelial cells inhibit granulocyte aggregation in vitro. J Immunol 136:3839-3847

23. Bevilacqua MP, Pober JS, Wheeler ME, Cotran RS, Gimbrone MA Jr. 1985 Interleukin 1 acts on cultured human vascular endothelium to increase the adhesion of polymorphonuclear leukocytes, monocytes, and related leukocyte cell lines. J Clin Invest 76:2003-2011

24. McIntyre TM, Zimmerman GA, Prescott SM 1986 Leukotrienes $C_{4}$ and $D_{4}$ stimulate human endothelial cells to synthesize platelet-activating factor and bind neutrophils. Proc Natl Acad Sci USA 83:2204-2208

25. Schleimer RP, Rutledge BK 1986 Cultured human vascular endothelial cells acquire adhesiveness for neutrophils after stimulation with interleukin-1, endotoxin, and tumor-promoting phorbol diesters. J Immunol 136:649-654

26. Pohlman TH, Stannes KA, Beatty PG, Ochs HD, Harlan JM 1986 An endothelial cell surface factor(s) induced in vitro by lipopolysaccharide, interleukin-1, and tumor necrosis factor-alpha increases neutrophil adherence by a $\mathrm{CDw}_{18}$-dependent mechanism. J Immunol 136:4548-4553

27. Schapira M, Despland E, Scott CF, Boxer LA, Colman RW 1982 Purified human plasma kallikrein aggregates human blood neutrophils. J Clin Invest 69:1199-1201

28. Seniro RM, Skogen WF, Griffin GL, Wilner GD 1986 Effects of fibrinogen derivatives upon the inflammatory response. J Clin Invest 77:1014-1019

29. Colman RW 1984 Surface-mediated defense reactions. The plasma contact activation system. J Clin Ivest 73:1249-1253

30. Harlan JM, Killen PD, Senecal FM, Schwartz BR, Yee EK, Taylor RF, Beatty PG, Price TH, Ochs HD 1985 The role of neutrophil membrane glycoprotein GP-150 in neutrophil adherence to endothelium in vitro. Blood 66:167-178

31. Perez HD, Ong R, Khanna K, Banda D, Goldstein IM 1982 Wheat germ agglutinin specifically inhibits formyl peptide-induced polymorphonuclear leukocyte chemotaxis. J Immunol 129:2718-2724

32. Gray BM, Dillon HC Jr, Pritchard DG 1984 Interaction of group B streptococcal type-specific polysaccharides with wheat germ agglutinin and other lectins. J Immunol Methods 72:269-277

33. O'Flaherty JT, Wykel RL, Lees CJ, Shewmake T, McCall CE, Thomas MJ 1981 Neutrophil-degranulating action of 5,12-dihydroxy-6,8,10,14-eicosatetraenoic acid and 1-0-alkyl-2-0-acetyl-sn-glycero-3-phosphocholine. Am J Pathol 105:264-269

34. Shigeoka AO, Hall RT, Hemming VG, Allred CD, Hill HR 1978 Role of antibody and complement in opsonization of group B streptococci. Infect Immunol 21:34-40

35. Wood EG, Gray BM 1986 Type-specific antibody prevents platelet aggregation induced by group B streptococci type III. J Lab Clin Med 107:322-326

36. Christensen RD, Rothstein G, Hill HR, Pincus SH 1983 The effect of hybridoma antibody administration upon neutrophil kinetics during experimental type III group B streptococcal sepsis. Pediatr Res 17:795-799

37. Brigham KL, Meyrick B 1984 Interactions of granulocytes with the lungs. Circ Res 545:623-635 